\title{
EFEKTIVITAS EKSTRAK DAUN PEPAYA DALAM PENGENDALIAN KUTU DAUN PADA FASE VEGETATIF TANAMAN TERUNG
}

\author{
Riski Ramadhona ${ }^{1}$, Djamilah $^{1 *}$, Mukhtasar ${ }^{1}$ \\ ${ }^{1}$ Program Studi Agroekoteknologi, Fakultas Pertanian, Universitas Bengkulu \\ * Corresponding Author :djamilah@unib.ac.id
}

\begin{abstract}
[EFFICACY OF PAPAYA LEAF EXTRACT IN CONTROLLING COTTON APHID DURING VEGEATIVE GROWTH STAGE OF EGGPLANT]. Cotton aphid (Aphis gossypii Glover) can cause serious economic losses in the eggplant production. The application of synthetic pesticides can be effective in controlling the pest but it may not be the best solution for the human health and environment. Botanical pesticides have long been known for their potential as the alternative to synthetic pesticides for crop protection with reduced risk to human health and environmental hazard. Objective of this study was to compare the efficacy of papaya leaf extract solutions in controlling cotton aphid and their effect on the vegetative growth of eggplant. Papaya leaf extract solutions differing in concentration $(0 \%, 10 \%, 20 \%, 30 \%, 40 \%$, and $50 \%)$ were sprayed onto aphid infested eggplants to observe the insect mortality, crop damage, and the lethal concentration at LC50 and LC90. The mortality of aphid was significantly increased following the application of papaya leaf extract, with the highest mortality $(91.33 \%)$ was found on the concentration of $50 \%$. The lethal concentrations of the extract causing $50 \%$ (LC50) and $90 \%$ (LC90) aphid mortality were $9.98 \%$ and $41.99 \%$, respectively. As compared to the control treatment, the crop damage was significantly reduced by the application of the papaya leaf extract solution.
\end{abstract}

Keyword: botanical pesticide, papaya leaf, Aphis gossypii, eggplant

\begin{abstract}
ABSTRAK
Serangan kutu daun Aphis gossypii Glover secara ekonomis sangat merugikan dalam budidaya terung. Penggunaan pestisida sintetis dapat menjadi metode pengendalian yang efektif terhadap hama tersebut namun bukan menjadi penyelesaian terbaik jika dikaitkan dengan kesehatan manusia dan lingkungan. Pestisida nabati telah lama dikenal sangat potensial sebagai alternatif dari pestisida sintetis dalam pengendalian hama dengan resiko kesehatan manusia dan keruskan lingkungan yang sangat rendah. Penelitian ini bertujuan untuk membandingkan efikasi larutan ekstrak daun papaya dalam mengendalian kutu daun dan pengaruhnya terhadap pertumbuhan vegetatif tanaman terung. Larutan ekstrak papaya dengan konsetrasi berbeda $((0 \%, 10 \%, 20 \%, 30 \%, 40 \%$, dan $50 \%)$ disemprotkan pada tanaman terung yang sebelumnya telah diinfestasikan dengan kutu daun untuk diamati tongkat mortalitas serangga, tingkat kerusakan tanaman, dan konsentrasi letal pada LC50 dan LC90. Mortalitas serangga mengalami peningkatan yang nyata akibat penyemprotan larutan ekstrak daun pepaya, dengan mortalitas tertinggi $(91,33 \%)$ dijumpai pada konsentrasi 50\%. Konsentrasi larutan yang menyebabkan kematian serangga 50\% (LC50) dan 90\% (LC90), masingmasing ditemukan pada konsentrasi $9,98 \%$ dan $41,99 \%$. Dibanding dengan perlakuan kontrol, tingkat kerusakan tanaman mengalami penurunan yang nyata akibat penyemprotan larutan ekstrak daun papaya.
\end{abstract}

Kata kunci: pestisida nabati, daun pepaya, Aphis gossypii, tanaman terung 


\section{PENDAHULUAN}

Terung merupakan komoditas pertanian yang dibutuhkan di Indonesia, hal ini disebabkan terung mempunyai kandungan gizi cukup lengkap dan nilai ekonomis yang tinggi.Tanaman terung banyak mengandung kalium dan vitamin A yang berguna bagi tubuh. Komposisi kimia terung per $100 \mathrm{~g}$ yaitu air $92,70 \mathrm{~g}$; abu (mineral) $0,60 \mathrm{~g}$; besi $0,60 \mathrm{mg}$; karbohidrat $5,70 \mathrm{~g}$; lemak $0,20 \mathrm{~g}$; serat $0,80 \mathrm{~g}$; kalori 24,00 kal; fosfor 27,00 mg; kalium 223,00 $\mathrm{mg}$; kalsium $30,00 \mathrm{mg}$; protein $1,10 \mathrm{~g}$; natrium 4,00 mg; vitamin B3 0,60 mg; vitamin B2 0,05 mg; vitamin B1 10,00 mg; vitamin A 130,00 mg; dan vitamin C 5,00 mg berdasarkan data Direktorat Gizi (Budiman, 2008). Biasanya terung digunakan sebagai bahan makanan dan di Bengkulu diolah menjadi manisan terung sebagai oleh-oleh khas Bengkulu, selain itu digunakan sebagai bahan terapi, dan bahan kosmetik alami (Sunarjono et al.,2013), untuk obat dapat menetralkan pembuluh darah arteri dan anti kanker (Iritani, 2012).

Kutu daun (Aphis gossypii Glover) merupakan jenis hama yang penting dalam budidaya terung, berbagai jenis sayuran lainnya. Serangga yang ternasuk dalam famili Aphididae ordo Homoptera tersebut memiliki berwarna tubuh hijau, kuning dan coklat kehitaman bahkan hitam, berkembang biak secara partenogenesis (tanpa kawin), dan biasanya berkoloni di bawah permukaan daun atau sela-sela daun yang terhindar dari sinar matahari. Serangga ini menyerang dengan cara menusukkan stiletnya dan mengisap cairan sel tanaman pada bagian daun, tangkai daun. Serangan menyebabkan pucuk atau daun tanaman keriting, daun tumbuh tidak normal, dan menggulung, kerusakan pada ujung tanaman dapat merusak pertumbuhan tanaman (Kalshoven, 1981). Hama ini tidak hanya menghisap cairan tanaman tetapi juga sebagai vektor penyakit yang disebabkan virus (Romosher, 1998). Kotoran yang dikeluarkan serangga berupa embun madu yang disukai semut dan embun madu tersebut akan menjadi media tumbuh bagi cendawan jelaga yang menutupi permukaan daun sehingga fotosintesis tanaman akan terganggu karena sinar matahari terhalang menyinari daun. Kerugian akibat serangan A.gossypii dapat mencapai $10-30 \%$ selain musim kemarau sementara saat musim kemarau mampu mencapai $40 \%$, sebagai vektor menyebabkan kerugian sebesar 90\% (Khodijah, 2014).

Menurut Bagwell \& Baldwin (2009) penggunaan pestisida sintetis untuk mengendalikan $A$. gossypii memiliki banyak kekurangan.Pemakaian pestisida sintetis dapat meninggalkan residu zat kimia sintetis pada hasil pertanian, sehingga kurang baik untuk kesehatan. Selain itu aplikasi pestisida sintetis secara terus-menerus menyebabkan resistensi hama, resurgensi hama, timbulnya hama sekunder, matinya serangga mengguntungkan dan musuh alami serta mencemarkan lingkungan (Pracaya, 2007). Sebaiknya musuh alami A. gossypii dan serangga menguntungkan dipertahankan dengan cara memanipulasi habitat sekitar tanaman budidaya. Keanekaragaman tumbuhan yang berada di sekitar tanaman budidaya mempengaruhi kehadiran predator dan parasitoid $A$. gossypii (Brewer \& Elliot, 2004; Riyanto, 2012). Salah satu cara konservasi serangga yang menguntungkan adalah dengan sistem pertanian organik (Syahrawati \& Hamid, 2010).

Penggunaan pestisida sintetis yang dinilai praktis untuk mengendalikan serangan hama nyatanya memberikan dampak negatif bagi lingkungan sekitar bahkan bagi penggunanya sendiri, sehingga dibutuhkan suatu alternatif lain yang dampak negatifnya kecil seperti pestisida nabati yang ramah lingkungan. Pestisida nabati adalah pestisida yang bahan dasarnya berasal dari tumbuhan yang relatif mudah dibuat dengan kemampuan yang terbatas, karena pestisida nabati bersifat mudah terurai (Grdisa \& Grsic, 2013).

Beberapa tumbuhan diketahui memiliki kandungan zat-zat kimia yang berpotensi untuk pengendalian hama pada tanaman (Dono et al., 2013). Pemanfaatan tumbuhan sebagai bahan aktif pestisida mulai banyak digunakan untuk pengendalian hama dan penyakit. Hal ini dikarenakan tumbuhan adalah sumber bahan kimia potensial yang dapat digunakan sebagai pestisida yang ramah lingkungan dan lebih aman secara kesehatan (Wiratno \& Trisawa, 2012). Di Indonesia bahan pestisida nabati banyak tersedia di alam. Sebanyak 37.000 spesies flora telah diidentifikasi dan baru sekitar 1\% yang telah dimanfaatkan (Djunaedy, 2009). Pestisida nabati selain ramah lingkungan juga merupakan pestisida yang relatif aman dalam penggunaannya dan ekonomis.

Pepaya merupakan tanaman yang memiliki potensi sebagai pestisida nabati untuk mengendalikan serangga hama. Papain yang terkandung alam daun pepaya bersifat meracun bagi ulat dan hama penghisap (Julaily, et al. 2013) . Papain merupakan enzim proteolitik, yaitu enzim yang dapat mengurai dan memecah protein dan berpotensi sebagai pestisida (Robert \& Bryony, 2010). Namun demikian, penggunaan daun papaya sebagai insektisida nabati untuk mengendalikan hama, terutama kutu daun pada sayuran belum banyak dilakukan. Karena itu, informasi yang terkait dengan takaran ekstrak daun pepaya yang efektif untuk pengendalian hama kutu daun terung masih sangat terbatas. Penelitian ini bertujuan untuk membandingkan konsentrasi ekstrak daun pepaya dalam mengendalikan $A$. gossypii dan pengaruhnya terhadap pertumbuhan tanaman terung.

\section{METODE PENELITIAN}

Penelitian ini dilaksanakan pada bulan MaretJuni 2016 di lahan Fakultas Pertanian Universitas Bengkulu. Rancangan Acak Lengkap (RAL) dengan 5 ulangan digunakan untuk menempatkan enam perlakuan konsentrasi larutan ekstrak daun papaya 
$(0,10,20,30,40$ dan $50 \%)$ pada satuan percobaan yang terdiri atas 1 tanaman terung yang ditumbuhkan pada polybag berukuran $30 \mathrm{~cm}$ x $30 \mathrm{~cm}$.

Bahan tanam yang digunakan dalam penelitian ini adalah benih terung hibrida varietas 'Pandega'. Bibit tanaman disiapkan pada tray dengan media campuran tanah dan pupuk kandang (3: $1 \mathrm{v} / \mathrm{v})$ hingga berumur 2 minggu untuk selanjutnya dipindah-tanam pada polybag yang berisi campuran tanah dan pupuk kandang $(1: 1 \mathrm{v} /$ v) dengan populasi 1 tanaman untuk tiap polybag dan disungkup plastik dengan panjang $60 \mathrm{~cm}$ dan lebar 40 $\mathrm{cm}$. Pemeliharaan tanaman dilakukan secara manual dan tidak melibatkan penggunaan bahan kimia sintetik.

Imago $A$. gossypii yang diperoleh dari tanaman kacang panjang diinfestasikan ke tanaman terung yang telah berumur 3 minggu untuk dipelihara dan perbanyakan serangga dilakukan selama 3 minggu hingga jumlah $A$. gossypii lebih dari 900 imago untuk memenuhi kebutuhan percobaan. Selanjutnya, serangga tersebut diinfestasikan kepada tanaman terung yang telah berumur 4 minggu dengan populasi 30 serangga tanaman ${ }^{-1}$.

.Larutan induk ekstrak daun papaya dibuat dengan cara melumatkan $3 \mathrm{~kg}$ daun yang telah dikeringanginkan selama 3 hari dalam $3 \mathrm{~L}$ air menggunakan blender. Campuran tersebut selanjutnya dimasukkan ke dalam toples plastik tertutup dan setelah didiamkan selama 24 jam disaring dengan kertas saring. Untuk penggunaannya, larutan induk dicampur dengan air sesuai dengan konsentrasi perlakuan lalu setiap konsentrasi dimasukkan ke dalam semprotan tangan. Penyemprotan dilakukan setelah hama $A$. gossypii diinfestasikan dan telah dibiarkan selama 12 jam. Setiap tanaman disemprot satu kali pada sore hari sesuai dengan perlakuan yang telah ditentukan sebanyak $\pm 10 \mathrm{ml}$ per tanaman selanjutnya dilakukan pengamatan mortalitas hama 12 jam setelah penyemprotan.

Data dikumpulkan melalui pengamatan mortalitas total, kerusakan tanaman, $\mathrm{LC}_{50}$, dan $\mathrm{LC}_{90}$. Mortalitas serangga diukur sebagai mortalitas $=(\mathrm{a} / \mathrm{a}+\mathrm{b}) \mathrm{x}$ $100 \%$ dengan $\mathrm{a}=$ jumlah $\mathrm{A}$. gossypii yang mati dan $\mathrm{b}=$ jumlah A. gossypii yang mati (Aldiwaridha, 2010):. Kerusakan tanaman diukur sebagai $\mathrm{P}=\left(\sum\right.$ $(\mathrm{n} \times \mathrm{v}) /(\mathrm{Z} \times \mathrm{N})) \times 100 \%$ dengan $\mathrm{P}=$ Kerusakan tanaman, $\mathrm{n}=$ Jumlah strata daun dari tiap kategori kerusakan, $\mathrm{v}=$ Nilai skala dari tiap kategori kerusakan, $Z=$ Nilai skala dari kategori kerusakan tertinggi, dan $\mathrm{N}=$ Jumlah daun yang diamati tiap tanaman (Nugroho et al., 2013). Berdasarkan nilai $\mathrm{P}$, tingkat kerusakan tanaman dikatergorikan sebagai berikut: sehat $(\mathrm{P}=0 \%)$, sangat ringan $(\mathrm{P}$ $=1-20 \%)$, ringan $(\mathrm{P}=21-40 \%)$, sedang $(\mathrm{P}=41$ $-60 \%)$, dan berat $(\mathrm{P}=61-80 \%)$. $\mathrm{LC}_{50}$, dan $\mathrm{LC}_{90}$ ditetapkan melalui analisis probit (Negara, 2003).

Data hasil pengamatan dianalisis secara statistik dengan analisis varian pada uji $\mathrm{F}$ dengan taraf 5\%. Uji beda nyata terkecil (BNT) pada taraf
5\% dilakukan untuk membandingkan rata-rata perlakuan. Sebelum dianalisis data mortalitas serangga dan kerusakan tanaman ditransformasi dengan Arc Sin. Analisis data dilakukan dengan menggunakan aplikasi Costat.

\section{HASIL DAN PEMBAHASAN}

\section{Mortalitas dan perubahan fisik Aphis gossypii Glover}

Hasil analisis varian menunjukkan bahwa ekstrak daun pepaya berpengaruh nyata terhadap mortalitas serangga dan kerusakan tanaman. Mortalitas serangga mengalami peningkatan seiring dengan meningkatnya konsentrasi ekstrak daun papaya (Tabel 1). Kenaikan konsentrasi pestisida nabati diikuti dengan naiknya mortalitas A. gossypii. Hasil penelitian Konnoet al. (2004) menunjukkan bahwa getah pepaya mengandung kelompok enzim sistein protease seperti papain dan kimopapain.Getah pepaya juga menghasilkan senyawasenyawa golongan alkaloid, terpenoid, flavonoid dan asam amino nonprotein yang sangat beracun pada serangga (Julaily et al., 2013).

Pada tanaman kontrol, mortalitas serangga hanya sebesar 3,3\% dan mortalitas tersebut dapat terjadi saat pemindahan $A$. gossypii ke tanaman. Namun besarnya mortalitas tersebut masih termasuk rendah $(<20 \%)$ sehingga data yang dihasilkan tidak memerlukan koreksi (Abbot, 1025). Mortalitas A. gossypii tertinggi $(91,3 \%)$ dicapai pada konsentrasi larutan ekstrak $50 \%$. Namun beberapa konsentrasi lebih rendah juga cukup efektif untuk menimbulkan kematian serangga. Mumford \& Norton (1984) mengemukakan bahwa suatu pestisida dapat dikatakan efektif apabila mampu mematikan minimal 80\% serangga uji. Dalam percobaan ini, konsentrasi ekstrak daun pepaya 30\% dapat dikategorikan efektif karena mampu mengakibatkan kematian $A$. gossypii sebesar $80,7 \%$ dan efektifitasnya meningkat ketika konsentrasi ekstrak daun papaya ditingkatkan. Sebaliknya, Prijono (2007) berpendapat bahwa suatu pestisida dapat dikatakan efektif apabila mampu mematikan serangga lebih dari 90\%. Hal ini berarti bahwa hanya ekstrak daun pepaya dengan konsentrasi $50 \%$ yang dapat dikategorikan efektif.

Perubahan pergerakan $A$. gossypi yang terjadi setelah hama disemprot dengan ekstrak daun pepaya mengakibatkan tungkai $A$. gossypii bergerak lemah atau pasif dan kaku yang pada awalnya terlihat bergerak aktif. Nursal et al. (1997) menyatakan bahwa senyawa toksin yang terkandung dalam pestisida nabati adalah senyawa yang dapat menyebabkan bagian tubuh serangga menjadi kaku, sehingga aktivitas serangga akan terganggu dan menurunkan aktivitas metabolisme tubuh dan pencernaan. Perubahan $A$. gossypiiterlihat juga adanya perubahan fisik $A$. gossypii yaitu pada warna tubuh dan kondisi tubuh.Warna tubuh kehitaman atau yang hampir 
hitam mengkilat menjadi pucat sehingga warnanya menjadi cenderung coklat abu-abu dan gejala lanjutan kondisi tubuh $A$. gossypii terlihat mengisut dan kaku serta kutikula $A$. gossypii yang mengelupas (Gambar 1.).

Enzim papain merupakan racun kontak yang langsung masuk ke dalam tubuh hama melalui lubang-lubang alami dari tubuhnya. Setelah masuk, racun akan menyebar ke seluruh tubuh dan menyerang sistem saraf sehingga dapat menganggu aktivitas hama (Untung 2006). Enzim papain juga berfungsi sebagai enzim protease yang dapat menyerang dan melarutkan komponen penyusun kutikula serangga pada tanaman yang telah disemprot dengan ekstrak daun pepaya. Senyawa aktif pestisida nabati yang masuk ke tubuh $A$. gossypii mengganggu aktivitas makan dan menyebabkan kurangnya asupan nutrisi yang dibutuhkan tubuh oleh serangga untuk pertumbuhannya (Dono \& Rismanto, 2008). Toksin yang terkandung dalam senyawa papain juga merupakan racun kontak dan racun perut. Hasil penelitian Julaily et al. (2013) menunjukkan bahwa penggunaan ekstrak daun pepaya dapat memutuskan atau menggagalkan metamorfosis hama yang memiliki metamorfosis sempurna sementara pada hama yang bermetamorfosis tidak sempurna dapat mematikan.Hasil penelitian ini menunjukkan bahwa ekstrak daun pepaya dapat menyebabkan hama yang menyerang tanaman sawi hanya berkembang sampai pada tahap perkembangan larva kemudian mati. Metamorfosis tersebut gagal akibat senyawasenyawa toksin yang merusak jaringan saraf, seperti senyawa alkaloid yang menghambat proses larva menjadi pupa (Wiratno, 2010). Hasil penelitian Siahaya \& Rumthe (2014) juga menunjukkan bahwa penggunaan ekstrak daun daun pepaya dapat mengakibatkan gagalnya metamorfosis pada ulat Plutella xylostella. Senyawa-senyawa aktif seperti alkaloid, saponin, flavonoid, terpenoid dan enzim papaindapat mempengaruhi beberapa sistem fisiologis yang mengatur perkembangan hama yang biasa menyerang tanaman (Sastrodihardjo et al., 1992).

Tabel 1. Mortalitas Aphis gossypii pada berbagai perlakuan konsentrasi ekstrak daun papaya hingga 7 hari setelah aplikasi.

\begin{tabular}{cc}
\hline $\begin{array}{c}\text { Konsentrasi } \\
\text { ekstrak (\%) }\end{array}$ & $\begin{array}{c}\text { Mortalitas } \\
(\%)\end{array}$ \\
\hline 0 & $3,25 \mathrm{c}$ \\
10 & $76,0 \mathrm{~b}$ \\
20 & $77,3 \mathrm{~b}$ \\
30 & $80,7 \mathrm{~b}$ \\
40 & $81,3 \mathrm{~b}$ \\
50 & $91,3 \mathrm{a}$ \\
\hline
\end{tabular}

Keterangan: Angka-angka yang diikuti huruf yang berbeda pada kolom yang sama menunjukkan berbeda nyata pada Uji BNT pada taraf $5 \%$.

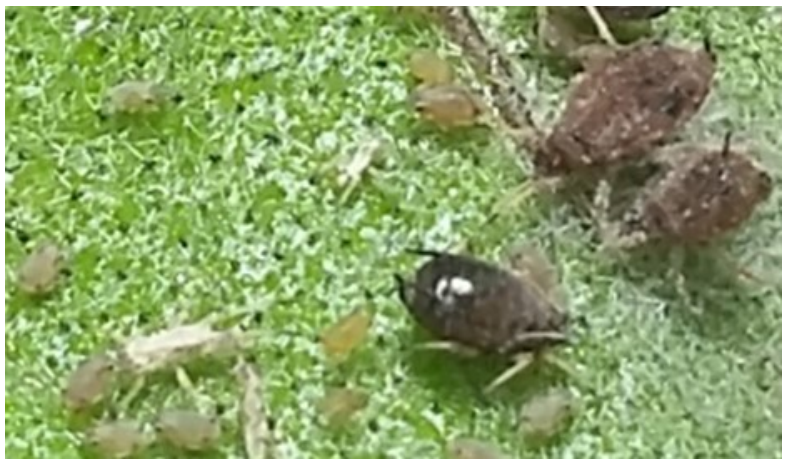

Gambar 1. Aphis gossypii Glover pada daun tanaman terung (a) A. gossypii Glover mati, (b) A. gossypii Glover sehat

\section{Populasi Aphis gossypii Glover dan kerusakan tanaman}

Penggunaan ekstrak daun pepaya dapat menurunkan populasi $A$. gossypii pada tanaman terung. Penurunan populasi $A$. gossypii dengan ekstrak daun pepaya yang diaplikasikan setelah hama diinfestasikan dapat dilihat sampai pengamatan hari ke-3, namun pada hari ke-4 dan seterusnya cenderung mengalami peningkatan. Populasi $A$. gossypii yang meningkat diduga terjadi karena adanya $A$. gossypii yang belum mati akibat pengaplikasian pestisida nabati daun pepaya, sehingga $A$. gossypii yang hidup masih mengalami perkembangbiakan.Seekor imago dapat melahirkan 1-4 ekor nimfa dengan rata rata 4,3 ekor nimfa perhari, sedangkan keperidian rata-rata imago 67 nimfa (Ebeling, 1951). Dinamika populasi A. gossypii pada tanaman terung dapat dilihat pada Gambar 2. Kecenderungan kenaikan populasi $A$. gossypii yang terjadi mulai hari ke-4 sesudah aplikasi ekstrak daun pepaya dapat terjadi karena ekstrak tersebut mengalami penguraian dan hilang dari permukaan tanaman (Grdisa \& Grsic, 2013). Agar penggunaan pestisida nabati dari ekstrak daun pepaya sesuai keinginan dan mendapatkan hasil yang lebih baik dalam pengendalian A. gossypii, maka penyemprotan tanaman lebih dari sekali atau dalam rentang waktu empat hari perlu dilakukan agar $A$. gossypii yang belum mati dapat dikendalikan.

Kerusakan tanaman terung akibat serangan $\mathrm{Aphis}$ gosypii Glover disajikan pada Tabel 2. Secara umum, aplikasi ekstrak daun papaya dapat menurunkan tingkat kerusakan daun dibandingkan dengan kontrol, dengan kisaran 17,1 hingga 12,9\%. Gejala kerusakan dalam bentuk daun menjadi keriting akibat sel-sel yang dihisap serangga terhambat pertumbuhan dan perkembangannya, sementara sel-sel yang tidak dihisap dapat tumbuh dan berkembang dengan normal. Namun demikian, sifat toksin dari pestida nabati yang diaplikasikan mampu menurunkan kemampuan serangga dalam mencerna makanan dan pada 
akhirnya menunkan tingkat kerusakan tanaman sebagaimana dilaporkan oleh Hasnah (2009) yang menggunakan ekstrak buah mengkudu untuk mengendalikan Plutella xylostella L. pada tanaman sawi. Demikian juga, tingkat serangan $A$. gossypii tersebut terkait dengan fluktuasi populasinya pada pertanaman, populasi yang rendah akibat aplikasi pestisida nabati cenderung menyebabkan kerusakan tanaman yang lebih rendah (Khodijah, 2014).

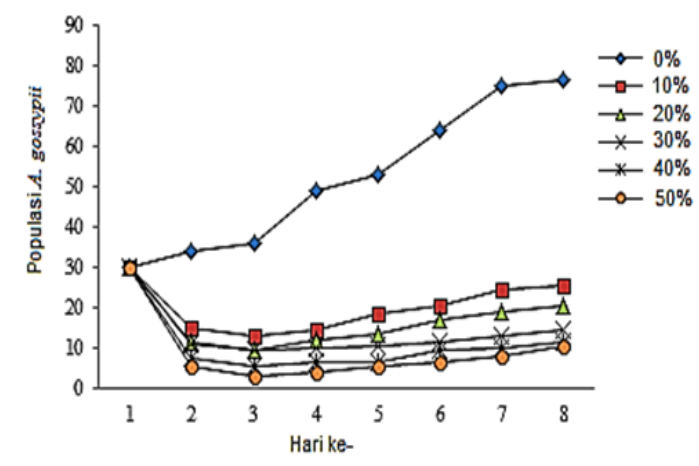

Gambar 2. Populasi Aphis gossypii Glover pada tanaman terung selama 7 hari pengamatan dengan pengaplikasian pestisida nabati daun pepaya dengan berbagai konsentrasi

Tabel 2. Kerusakan tanaman terung akibat serangan Aphis gosypii Glover yang disemprot ekstrak daun papaya.

\begin{tabular}{cc}
\hline Konsentrasi ekstrak (\%) & $\begin{array}{c}\text { Kerusakan tanaman } \\
(\%)\end{array}$ \\
\hline 0 & $26,3 \mathrm{a}$ \\
10 & $17,1 \mathrm{~b}$ \\
20 & $16,0 \mathrm{~b}$ \\
30 & $16,0 \mathrm{~b}$ \\
40 & $15,6 \mathrm{~b}$ \\
50 & $12,9 \mathrm{~b}$ \\
\hline
\end{tabular}

Keterangan : Angka-angka yang diikuti huruf yang berbeda pada kolom yang sama menunjukkan berbeda nyata pada uji BNT pada taraf 5\% berdasarkan data transformasi.

\section{$L C_{50}$ dan $L C_{90}$}

Efektivitas ekstrak daun pepaya yang diaplikasikan untuk mengendalikan A. gossypii dapat diukur berdasarkan nilai LC50 dan LC90, yaitu konsentrasi insektisida yang diperlukan untuk mematikan $A$. gossypii berturutturut sebanyak $50 \%$ dan $90 \%$ serangga uji. Hasil analisis menunjukkan bahwa untuk dapat membunuh $50 \%$ dan $90 \%$ hama uji diperlukan ekstrak daun pepaya dengan konsentrasi $10,0 \%$ dan $42,0 \%$.

\section{KESIMPULAN}

Ekstrak daun pepaya merupakan insektisida nabati yang cukup efektif untuk mengendalikan $A$. gossypii yang menyerang tanaman terung. Pada konsentrasi $30 \%$ dapat menyebabkan kematian serangga tersebut hingga mortalitas $80,7 \%$ dan cenderung meningkat mortalitasnya seiring peningkatan konsentrasi yang diaplikasikan. Kerusakan tanaman terung juga dapat dikurangi antara $17,1 \%$ hingga $12,9 \%$ se-telah A. gossypii dikendalikan dengan ekstrak daun papaya. Konsentrasi mematikan, yaitu LC50 dan LC90, dicapai masing-masing pada konsentrasi $10,0 \%$ dan $42,0 \%$.

\section{DAFTAR PUSTAKA}

Abbott, W. S. (1925). A method of computing the effectiveness of an insecticide. J. econ. Entomol, 18(2), 265-267.

Negara, A. (2003). Penggunaan analisis probit untuk pendugaan tingkat kepekaan populasi Spodoptera exigua terhadap deltametrin di Daerah Istimewa Yogyakarta. Informatika Pertanian, 12, 1-9.

Aldiwaridha. (2010). Uji efektifitas insektisida botani terhadap hama Maruca testulalis (Geyer) (Lepidoptera: Pyralidae) pada tanaman kacang panjang (Vigna sinensis). Jurnal Ilmiah Abdi Ilmu, 3(2), $1-10$.

Bagwell, R. D., \& Baldwin, J. L. (2009). Aphids on cotton. Louisiana State University (LSU) Agricultural Center, Center Research and Extension.

Budiman, E. (2008). Cara dan Upaya Budidaya Terung. CV. Wahana Iptek, Bandung.

Djunaedy, A. (2009). Biopestisida sebagai pengendali organisme pengganggu tanaman (OPT) yang ramah lingkungan. Embryo, 6(1), 88-95.

Dono, D., \& Rismanto, R. (2008). Aktivitas Residu Ekstrak Biji Barringtonia asiatica (L.) Kurz. Terhadap larva Crocidolomia pavonana F.(Lepidoptera: Pyralidae). Agrikultura, 19(3), 184-189.

Dono, D., Natawigena, W. D., \& Majid, M. G. (2012). Bioactivity of methanolic seed extract of Barringtonia asiatica L.(Kurz)(Lecythidaceae) on biological characters of Spodoptera litura (Fabricius)(Lepidoptera: Noctuidae). Int Res $J$ Agric Sci Soil Sci, 2, 469-475.

Ebeling, W. (1951). Sub tropical entomology. Experiment Station University of California, L.A.

Grdiša, M., \& Gršić, K. (2013). Botanical insecticides in plant protection. Agriculturae Conspectus Scientificus, 78(2), 85-93. 
Hasnah, H. (2009). Efektivitas ekstrak buah Mengkudu (Morinda citrifolia L.) terhadap mortalitas Plutella xylostella L. pada tanaman Sawi. Jurnal Floratek, 4(1), 29-40.

Iritani, G. (2012). Vegetable Gardening. Indonesia Tera. Yogyakarta.

Julaily, N., \& Mukarlina, T. R. S. (2013). Pengendalian hama pada tanaman Sawi (Brassica juncea L.) menggunakan ekstrak daun Pepaya (Carica papaya L.). Protobiont, 2(3).

Kalshoven L.G.C. (1981). Pest of crop in Indonesia. Ichtiar Baru, Jakarta.

Khodijah. (2014). Kelimpahan serangga predator kutu daun Aphis gossypii di sentra tanaman sayuran di Sumatera Selatan. Biosaintifika, 6 (2), 76-84.

Konno, K., Hirayama, C., Nakamura, M., Tateishi, K., Tamura, Y., Hattori, M., \& Kohno, K. (2004). Papain protects papaya trees from herbivorous insects: role of cysteine proteases in latex. The Plant Journal, 37(3), 370-378.

Mumford, J. D., \& Norton, G. A. (1984). Economics of decision making in pest management. Annual review of entomology, 29(1), 157-174.

Nugroho, Y., Mudjiono, G., \& Puspitarini, R.D. (2013). Pengaruh Sistem Pengendalian Hama Terpadu (PHT) dan Non PHT terhadap Tingkat Populasi dan Intensitas Serangan Aphid (Homoptera: Aphididae) pada Tanaman Cabai Merah . Jurnal Hama dan Penyakit Tumbuhan, 1(3), 85-95.

Nursal, E., Sudharto P.S., \& Desmier, R. (1997). Pengaruh Konsentrasi Ekstrak Bahan Pestisida Nabati Terhadap Hama. Balai Penelitian Tanaman Obat, Bogor.

Pracaya. (2007). Hama dan Penyakit Tumbuhan. Penebar Swadaya, Jakarta.

Riyanto, R. (20121). Kelimpahan Serangga Predator Kutu Daun (Aphis gossypii) (Glover) (Hemiptera: Aphididae) Sebagai Sumbangan Materi Kontekstual pada Mata Kuliah Entomologi di Program Studi Pendidikan Biologi FKIP UNSRI. In Seminar Kenaikan Pangkat FKIP Unsri (pp. 1-14). Pendidikan MIPA FKIP Universitas Sriwijaya, Palembang..
Harrison, R. L., \& Bonning, B. C. (2010). Proteases as insecticidal agents. Toxins, 2(5), 935-953.

Romoser, W. S., \& Stoffolano, J. G. (1998). The science of entomology. WCB, Singapore.

Sastrodihardjo, S., Adianto, \& M. Yusuf. (1992). The Impact of Several Insecticides on Ground and Water Communities. Proceedings SouthEast Asian Workshop on Pesticide Management, 7, 117-125.

Siahaya, Victor. (2014). Uji Ekstrak Daun Pepaya (Carica papaya) Terhadap Larva Plutella xylostella (Lepidoptera:Plutellidae). AGROLOGIA Jurnal Ilmu Budidaya Tanaman, 3, 112-116.

Sunarjono, H.A., A. Soetasad, \& S. Muryanti. (2013). Budidaya Terung Lokal dan Terung Jepang. Penebar Swadaya, Jakarta.

Syahrawati, M. \& H. Hamid. (2010). Diversitas Coccinellidae Predator pada Pertanaman Sayuran di Kota Padang. Lembaga Penelitian Universitas Andalas, Padang.

Untung, K. (2006). Pengantar Pengelolaan Hama Terpadu. Gadjah Mada University Press., Yogyakarta.

Wiratno, S. \& Trisawa, I..M. (2012). Perkembangan Penelitian, Formulasi dan Pemanfaatan Pestisida Nabati. Balai Pengkajian Teknologi Pertanian, Sumatera Selatan.

Wiratno. (2010). Beberapa formula pestida nabati dari cengkeh. J. Agritek, 13(1), 6-12. 